\title{
THE DYNAMICS OF ‘VIRTUOUS’ ORGANISATIONAL IDENTITY: THE CASE OF REGULATING OR ENABLING CORPORATE TAX COMPLIANCE
}

\author{
Penelope Tuck \\ Birmingham Business School, University of Birmingham
}

\begin{abstract}
$\mathrm{O}$ ur empirical study of a government regulatory agency examines how external stakeholders respond to policy-driven change in a way that potentially threatens organisational legitimacy. Specifically, we focus upon the United Kingdom (UK) tax agency, Her Majesty's Revenue and Customs (HMRC), and its move away from its traditional regulatory role towards enabling its 'customer', the corporate taxpayer, to 'shelter' tax. We theorise such policy as one of organisational identity change. Focusing upon organisational identity as 'moral', we highlight that should a government regulatory agency lose the support of external stakeholders as it engages in identity change, it may threaten the legitimacy and survival of that agency. Policy makers need to recognise that their power in defining organisational identity has its limits in public services organisations, where the public and media are likely to debate their moral purpose.
\end{abstract}

\section{INTRODUCTION}

Organisational identity is a well-established concept within generic management literature used to explain organisational change processes, content and outcomes (Brunsson and Sahlin-Andersson, 2000; Dutton and Dukerich, 1991; Golden-Biddle and Rao, 1997; Humphreys and Brown, 2002). Following behind this, there is emerging commentary within public administration literature that similarly examines the identity change of public services organisations (PSOs) (Meyer and Hammerschmid, 2006; Rondeaux, 2006; Skalen, 2004; Waeraas, 2010). However, as yet, the public administration literature about organisational identity is still relatively under-developed. Our study extends the recent public administration literature 
about organisational identity change and focuses upon how such change threatens the legitimacy of PSOs, as perceived by external stakeholders. By doing this, it also extends the tax administration and tax policy literatures.

Empirically, our study examines organisational identity change in a government regulatory agency, the UK tax agency, Her Majesty's Revenue and Customs (HMRC). Driven by policy exhortation to do so, senior management in HMRC has sought to move away from its traditional regulatory role towards enabling its 'customer', the corporate taxpayer, to 'shelter' tax.

Theoretically, we show change in organisational identity does not prove a straightforward matter. Any attempted change in organisational identity impacts the legitimacy ascribed to PSOs by external stakeholders (Brunsson and SahlinAndersson, 2000; Rondeaux, 2006; Skalen, 2004). In theorising how organisational identity might be viewed by external stakeholders, we focus upon the need for a PSO to maintain a 'virtuous' identity in order to retain legitimacy (Moore, 2005, 2012). This is important for policy makers and senior managers to understand. Should a PSO fail to sustain its identity as one imbued with moral purpose to external stakeholders, then it risks undermining its legitimacy and its survival may be threatened (Cheney and Vibbert, 1987; Dutton and Dukerich, 1991; Waeraas, 2010). This is particularly important in the case of tax collection. There is a social contract between citizens and the state such that 'taxes are what we pay for civilized society' (Oliver Wendell Holmes, Jr, United States Supreme Court Justice). If the state is discredited then taxpayers may not be so willing to pay their taxes to fund public goods.

This paper is structured as follows. First, we synthesise and critique the literature around organisational identity, discussing what might constitute a 'moral' or 'virtuous' organisation, and how this might apply to PSOs driven towards a greater customer-orientated identity. We then outline our case context and research design, following which data analysis is presented along three related themes: (i) Senior managers: 'Looking in the mirror'?; (ii) Corporate taxpayer: 'Tax avoidance (sheltering) isn't immoral, but we aren't customers'; and (iii) Public and media: 'Tax avoidance (sheltering) is immoral'. We conclude with a summary of our empirical case, where we highlight our theoretical contribution and policy implications, before calling for further research.

\section{LITERATURE REVIEW}

\section{Organisational Identity}

Organisational identity represents the interaction of internal social identity of managers and employees, and the external image of an organisation held by others, such as customers and the public (Ashforth and Mael, 1996; Hatch and Schultz, 2002). The concept of organisational identity was first developed by Albert and Whetten (1985) and subsequently the definition of the concept has become dynamic, in flux and often contested, as it responds to change (Gioia, Schultz and Corley, 2000; Scott and Lane, 2000a, 2000b). There are four major approaches to organisational identity: functionalist, social constructionist, psychodynamic and postmodern (He and 
Brown, 2013). In this study we take a social constructionist approach as the political influences create a less stable and less rigid organisational identity. We focus upon the response of external audiences to policy-driven managerial attempts to manipulate organisational identity, and so focus upon organisational image (Hatch and Schultz, 2002). This represents an important matter, since a PSO must 'keep an eye on the mirror' as it engages in identity change, in order to retain legitimacy (Dutton and Dukerich, 1991).

Commencing with Weber, there is an important sociological tradition centred on the concept of legitimacy. Legitimacy in this sense follows Weber's theory, which is one that stresses the importance of followers' beliefs (Weber, 1964). Legitimacy is also a major concept in organisation and management studies (see Suchman, 1995) as well as being critical to public policy debates. Organisations must achieve legitimate status in their environments in order to guarantee resources and avoid claims that they are negligent, irrational or unnecessary (Meyer and Rowan, 1977). The literature highlights that the external audience value accountability and reliability in organisations, and has documented risk associated with deviation from an established external identity (Hannan, Baron, Hsu and Kocak, 2006). Previous research on the link between organisational identity and legitimacy has shown that multiple organisational identities help to establish moral claims to legitimacy (Sillince and Brown, 2009); the construction of a legitimate sense of organisational identity is a combination of the performance of a stable identity over time together with distinguishing a different identity from other firms (Barney and Stewart, 2000) and is a function of level, locus, mechanism and approach (He and Baruch, 2010). In short, 'organizations need to adopt or possibly merely project identities that elicit legitimacy attributions' (Brown, 2001, p. 117). The importance of organisational image is reinforced by the media, which renders organisational identity more visible, as it exposes divergence between corporate images and organisational actions (Hatch and Schultz, 2002). As a consequence of its 'adaptive instability' (Gioia et al., 2000), senior managers' efforts to deliberately alter organisational identity are prone to challenge (Humphreys and Brown, 2002). Challenge to organisational identity from external stakeholders has been highlighted in cases where organisations invest in the culture of the customer (Du Gay, 2000) and in morally ambiguous contexts (Teram, 2010), such as public services settings.

\section{A Virtuous Organisational Identity}

In operationalising how organisational identity might be viewed by external stakeholders, we focus upon the need for a PSO to maintain a 'virtuous' identity in order to retain legitimacy. This is a concept grounded in MacIntyre's work (1984), After Virtue. To quote an introduction to a special issue about organisational virtue in Organization Studies (Nielsen, 2006, p. 317):

[MacIntyre] critically observed that, under the severe pressures of narrowly focused, systems driven, utilitarian financial and bureaucratic calculation, it can be very difficult both for organizations and individuals in their organizational lives to realize and express moral agency and virtue. 
This seems particularly relevant within PSOs, where delivery of service is increasingly utilitarian and coheres around the notion of customers and their sovereignty (Du Gay, 2000; Rosenthal and Peccei, 2007).

Moore has applied MacIntyre's work to contemporary organisations (Moore, $2005,2012)$, in a way that particularly resonates with our concerns about attempts to manipulate identity. Policy makers or senior managers within PSOs pursue external goods of effectiveness (MacIntyre, 1984), orientated towards the customer, such as enhancing customer satisfaction. However, this represents a fundamental challenge to the development of a virtuous organisation since the pursuit of external goods can corrupt the practice at the core of the organisation, i.e. could potentially 'kill' the organisation from the inside. In the case of HMRC, there exists a social and psychological contract so that citizens can expect to receive public services in return for paying taxation. Citizens can expect HMRC to collect the taxation due from taxpayers. Instead, the 'virtuous' organisation needs to preserve the practice at its core. This seems the essence of the attempted manipulation of organisational identity of HMRC towards customer orientation and enablement (representing external goods), which is not supported by the long-standing core practice of HMRC focused upon regulation. HMRC could then become a customer service provider (Tuck, 2013). Instead, developing an organisational identity for the common good requires a power-balanced structure that ensures the views and desires of particular constituencies are not privileged over others (Moore, 2005, 2012). This is particularly relevant in the case of PSOs, which are inherently more complex than private sector counterparts, with continuous contestation of their public purpose. Linked to this, PSOs should not see themselves as compartmentalised from other institutions in society, but part of a larger system, which delivers public goods. We detail this further in the next section of our paper.

\section{Organisational Identity of PSOs}

Questions of values and policies pervade PSOs, particularly at the point of delivery (Hoggett, 2006). Associated with New Public Management, a particular concept pervading policy is the idea of the 'sovereign' customer, as a figure of agency, enterprise and self-reliance, who is given choice in the public sphere and the means to exercise it (Hood, 1991). Even regulative organisations, such as tax agencies, which we would normally assume need legitimacy for their authoritative role and coercive powers, attempt to become identified with customer-orientated values. They put customers first (Aberbach and Christensen, 2007) and enact a more lenient identity, distancing themselves from the more 'traditional' authoritative and bureaucratic identity (Waeraas, 2010). However, the notion of the customer for public services delivery is one likely to be contested inside and outside PSOs (Berg, 2006; Bockel and Nooredegraff, 2006; Caron and Giauque, 2006; Horton, 2006; Korczynski and Ott, 2004; Needham, 2006; Thomas and Davis, 2005). With respect to tax agencies, being too customer-orientated is likely to challenge their core practice of regulation, on the basis the organisation is no longer 'virtuous' (Moore, 2005). Compliant taxpayers might question HMRC's approach if in their view HMRC was being too lenient to other taxpayers. 


\section{HMRC}

In this paper we specifically examine the dynamics of organisation identity in HMRC. A regulatory agency, such as HMRC, is likely to engage in strategic selfpresentation around its rule-enforcing function, its neutrality and its legitimate exercise of authority (Waeraas, 2010). However, HMRC has been subject to policy development to take on the role of 'enabler' of tax revenue collection, with associated emphasis upon users of its services as a customer (Her Majesty's Revenue and Customs, 2005, 2006, 2007, 2009). HMRC introduced the customer concept for internal purposes in the beginning of the 1990s (Tuck, 2013). Subsequently a change programme was introduced in 1992; one of its main themes was customer service (National Audit Office, 1996). The customer concept was further reinforced with the launch of the document 'The Whole Customer Vision, Practice and Design Principles (Her Majesty's Revenue and Customs, 2005). Associated with this, we suggest that HMRC is no longer the same organisation if its regulative activity is supplanted (Albert and Whetten, 1985; Waeraas, 2010). This represents an exemplary arena to examine our research concern, since there is a perpetual tension between regulation and enablement, which impacts organisational identity and legitimacy.

The corporate tax compliance process for large corporations is carried out by experts on both sides of the fence. The analogy of a game is frequently used to describe the interaction between tax inspectors in HMRC and their customers (Picciotto, 2007). In detail, under regulation, the tax agency would relate at arm's length with its corporate customers through a series of formal letters, which set out queries and calculations for the corporation's tax liabilities, to which the corporate customer would respond, with a final meeting at the end of the process to confirm liabilities. This tended to set the tax agency and corporate taxpayer against each other, as the latter sought to reduce the calculated tax liability. Further, should the corporate taxpayer fail to agree the calculation, then HMRC would start litigation proceedings and the matter would end up in the law courts.

In comparison, enablement requires HMRC to negotiate with the corporate taxpayer from the outset in a more proactive and relational manner. Reinforcing this more enabling approach, the role of 'client relationship manager' (commonly, former tax inspectors (tax agents) occupy this role) was introduced, responsible for interaction between HMRC and large corporate taxpayers (Her Majesty's Revenue and Customs, 2006). This reflects the changing relationship between HMRC and the corporate taxpayer, with the latter positioned as the 'customer', and performance agreements and targets for 'customer service' framing tax collection activity. The move from regulation to enablement represents a response to the ability of the corporate taxpayer to negotiate tax settlements where the law is unclear, or omits to foresee the tax implications of specific circumstances. The broader rationale for moving towards enablement was the reduction of regulation and the development of a more conducive national climate for business to flourish, i.e. where corporations are viewed primarily as creators of wealth, rather than taxpayers. If the UK is not viewed as a conducive tax regime to do business, then the corporate taxpayer, particularly multinational corporations (MNCs), may move their activity elsewhere, i.e. the government wants to avoid adversarial relationships with the corporate taxpayer (Duncan, 2006). 
Tuck

\section{RESEARCH DESIGN}

Our study is a single empirical case, which can be theoretically generalised to aid transferability of analysis (Eisenhardt, 1989; Yin, 2004). Our case is set in the UK, which is subject to neo-liberal policy reforms that are evident globally, but for which the UK has been described as a 'fast mover' (Martin, Currie and Finn, 2009). Global neo-liberal policy forces have exacerbated the flux and tension around the identity of PSOs, particularly those in the regulatory sphere (Hoggett, 2006; Waeraas, 2010). This is particularly so in contexts such as the police and prisons where users would not normally have been referred to as customers (Clarke, Newman, Smith, Vidler and Westmarland, 2007; Needham, 2006).

Consistent with an interpretive perspective on organisational identity (Brown, 2001), our data set focuses on the views of external organisational stakeholders towards identity change. Our data set comprises 55 semi-structured interviews; 25 of these were carried out with HMRC senior managers, purposively sampled as those managing the change towards enablement, including the chairman. Apart from the chairman, all senior management respondents had trained and worked as tax inspectors, a role, until recently, focused upon technical skills and arm's length regulation. They were thus well-placed to comment upon the change from regulation to enablement, including how external stakeholders perceive such changes. These are complemented by interviews with twelve partners of a 'Big 4 ' accountancy firm (who gave specialist tax advice to the tax and financial directors of MNCs), and eighteen tax directors of MNCs. Interviews lasted 60-120 minutes, and all except two were recorded and fully transcribed (in the latter, notes were taken during the interview and elaborated following the interview). We further elaborated upon the societal or public image of HMRC, through systematically collating documentation from parliamentary committees and media reports (high quality press, television news items, web searches) covering the ten years (2002-2012) over which interviewees reported change towards enablement had occurred. This constitutes an archive running to thousands of pages, which was themed by stakeholder group, further broken down to specific issues, including organisational identity change. In Gephart's (1993, p. 1469) terms, we were able to collate 'a substantial archival residue' from the different published sources.

Analysis of data was framed by themes from the organisational identity literature, but allowed for induction through emergence of novel insights (e.g. that HMRC senior managers raised concerns about enablement and subsequent organisational legitimacy), as the authors coded the interview transcripts and the documentary archive. Our emerging theoretical arguments were based on the interplay between theory and data (Eisenhardt, 1989). During this process, we enhanced the internal validity of our research through the construction of thematic narratives around organisational identity. External validity was created through systematically comparing HMRC senior managers', external stakeholders' and political/media perceptions of changing organisational identity (Miles and Huberman, 1994). We moved from raw data to the themes presented in our manuscript through successive rounds of coding (Pratt, 2009). As a means of supporting our analysis, findings were presented to internal and external stakeholders at professional network events. This 
elaborated findings in some instances (e.g. variation in senior managers' support for enablement), but more importantly allowed a check on the authenticity of our analysis (Yin, 2004).

\section{FINDINGS}

We derived three inter-linked themes around the response of external stakeholders to organisational identity change: (i) Senior managers: 'Looking in the mirror'?; (ii) Corporate taxpayer: 'Tax avoidance (sheltering) isn't immoral, but we aren't customers'; and (iii) Public and media: 'Tax avoidance (sheltering) is immoral'. Our interview quotes below illustrate that the moral purpose of HMRC is contested as senior management attempt to reconstruct organisational identity in a way only partially supported by corporate taxpayers, and with increasing outrage by the public and media.

\section{Senior Managers: 'Looking in the Mirror'?}

It is useful to set out the stance of HMRC senior management towards organisational identity change since it is not as straightforward as one might expect. Even the policy makers, who sought to drive change in organisational identity, appear caught between the desire to support the creation of wealth through enablement, and to ensure, through tax collection, that wealth is re-distributed via a more regulatory role. They hold on to the core practice that informs HMRC's traditional organisational identity of regulation, as succinctly captured in the following statement by one of its senior civil servants in HM Treasury:

We are committed to creating the right [emphasis added by authors] tax environment for business and individuals, which encourages enterprise and minimises red tape. In return, we expect everyone to pay their fair share. And where we see tax avoidance, we will crack down on it. That's particularly important at a time when the Government has had to make tough choices elsewhere (Her Majesty's Treasury and Her Majesty's Revenue and Customs, 2011, p. 3).

A senior manager in HMRC, who highlighted that his own identity remained aligned with technical expertise in applying tax legislation at arm's length, also questioned the relevance of the customer concept that accompanies enabling. He suggested, 'we have to call them customers even though they might not want to be' (Senior Manager \#13). It seems that some senior managers in HMRC were looking in the mirror (Dutton and Dukerich, 1991) and exhibiting concern about organisational legitimacy in the eyes of external stakeholders. Another senior manager, with significant technical experience as a tax inspector, also reported similar concern about organisational identity change:

It's not recognised that calling taxpayers 'customers' over-emphasises the enabling side of things at the cost of the regulating. Quite clearly we are here to regulate. We are not paid to enable. I think the enabling is significant, but it's a minor part of what we ought to be doing (Senior Manager \#3). 
Ambivalence about the enabling approach is increasingly evident from HMRC managers in the wake of the global financial crisis, with one senior manager further commenting, ' $\mathrm{a} £ 300$ million provision saving $£ 100$ million tax may be a drop in the ocean as far as the corporate is concerned, but it would still buy a lot of hospital beds in the UK' (Senior Manager \#19). Further, PricewaterhouseCoopers tax advisors report that HMRC managers have significantly changed their approach towards tax collection, and, even in the face of a move towards enabling, have firmed up more regulatory intervention in cases of what they consider excessive (abusive) tax avoidance (PricewaterhouseCoopers, 2013).

However, we note some other senior managers were much less aware of the legitimacy concerns associated with policy exhortation to move towards enablement: 'it is our job to facilitate normal commercial business' (Senior Manager \#8). They were not 'looking in the mirror' to assess how others see them, even in financially austere times.

In summary, we see that even policy makers and senior managers in HMRC do not necessarily 'buy' into the organisational identity change towards enablement they are meant to implement. This foreshadows resistance towards organisational identity change of HMRC from those external stakeholders, corporate taxpayers and the public, whom HMRC were meant to serve.

\section{Corporate Taxpayer: 'Tax Avoidance (Sheltering) Isn't Immoral, But We Aren't Customers'}

When confronted with the argument that there exists a moral imperative to pay tax, corporate taxpayers are resistant in three ways. We might expect them to support organisational identity change toward enablement that allows them to 'avoid' tax. However, we emphasise their support for tax avoidance is not predicated on their view of themselves as the 'customer' who should be 'enabled', but more on an economic and legal justification.

First, corporate taxpayers argue that the creation of wealth itself is important and beneficial for the UK, since tax revenues will increase, even as corporate taxpayers follow 'acceptable' tax avoidance policies. Conversely, a more confrontational approach from HMRC may result in reduction or even cessation of tax revenue, as corporate taxpayers move to more 'tax friendly' countries:

I think that the tax environment has changed quite dramatically for the worse. In order to stay competitive, it [the UK's tax regime] needs to change for the better because other systems are becoming more favourable. If companies don't want to engage with the UK's tax system, they don't need to (FTSE 100 Company Tax Director \#17).

Second, even if the creation of wealth itself is not held in high regard, corporate taxpayers argue that their 'moral' responsibility, as enshrined in law, is towards their shareholders, rather than more broadly towards UK citizens. That corporate taxpayers had a 'moral imperative' to pay taxes as demanded by law but would seek to morally minimise these on the basis they served shareholders as their main responsibility is central to statements made by company tax directors and their tax advisors about tax avoidance: 
[What] I find rather irritating is they are trying to introduce a fairly moralistic tone into tax payments... Clearly it is our duty to pay taxes as levied by the law but we are not in the business of paying tax any more than we have to and it is often overlooked by Revenue officials that the directors of these companies have fiduciary duties to their shareholders and paying excessive amounts of tax isn't the way you discharge your fiduciary duties (FTSE Company Tax Director \#13).

Indeed, they held the view that HMRC should remain an arm's length body that regulates and advises policy makers, but not one that enables:

I think that's an immoral point of view to take because I don't think there is any moral imperative to pay a particular amount of taxes, it seems the moral imperative comes from abiding within the laws that are there. But I think you need a clear set of laws which the government is responsible for putting in place and the Revenue is responsible for administering. I don't actually think the Revenue ought to have a view on how much tax is or isn't raised. I think the Revenue should have a view on whether there is unfairness or anomalies, which need removing but they shouldn't have a view on whether that's levied up or down. At the government level clearly there is a policy requirement to collect an amount of tax and there is a moral imperative on taxpayers to pay the amount of tax they ought to under law. There is no moral imperative for them to pay any tax at all if the law doesn't say they should, or any particular amount of tax and I think that's where the confusion comes from, particularly in the evasion, avoidance debates (Big 4 Tax Advisor \#2).

Third, there is some concern from corporate taxpayers regarding how they might be implicated in any debate about the morality of tax compliance. They argue this confuses wealthy individuals who seek to avoid tax with corporate taxpayers who seek to comply with the law. Responding to media coverage of tax avoidance:

I'm not entirely certain what audience they're speaking to when they say this [the morality argument]; I mean if they're talking to the general public, it doesn't do them much good in terms of outcomes, but I suppose they then bask in the sort of reflected glory that our [HMRC] is after these horrid people, but as a practical matter I'm left uncertain where it gets them. They may be speaking to government, but they don't need to write articles in the tax journals to speak to government; or they're speaking to people like me and I don't care what they say. What I want to know [is], is what I'm doing legal? Don't tell me about morality; is it legal? The law is there. If they write the law in a certain way, then they've written the law in a certain way and so therefore this attempt to compare me to the man who evades tax by hiding his income or puts his company into bankruptcy and avoids his tax really doesn't do anything for the relationship. To try to cast me in a miasma of all these horrid people who are legally but illegally legally avoiding tax really doesn't help at all (FTSE 100 Company Tax Director \#8).

To emphasise their stance, corporate taxpayers were keen to distance themselves from any characterisation as 'villains' who abusively avoid tax. Thus, they might be expected to support the changing identity of HMRC towards enablement, since this, we might expect, provides tax avoidance with regulatory legitimacy. Yet this did not prove the case. Corporate taxpayers are supportive of acceptable tax avoidance on the basis that they are the wealth creators, and they have a legal requirement to serve 
Tuck

their shareholders. They are not necessarily supportive of their re-positioning as a 'customer', which accompanies changing HMRC organisational identity towards enablement. We note that corporate taxpayers, as represented by their tax directors and advisors, perceived inconsistency and tension in the role and identity of HMRC, with some concern about the customer-focused discourse that HMRC promotes:

I told a previous director [of HMRC] quite vociferously that we aren't customers. In my view the customer of the HMRC is the Treasury. We are not customers, we are taxpayers. But I think what they are trying to say is, 'Yes, you are taxpayers, but in terms of service we provide you, we are acting not just as regulators, but also as facilitators, so to that extent you are customers' (FTSE 100 Company Tax Director \#12).

Indeed in the quote below, we see some cynicism from the corporate taxpayer regarding $\mathrm{HMRC}^{\prime}$ 's identity change towards an enabling organisation in which its customer orientation was central. Corporate taxpayers did not buy into the 'enchanting myth' of the sovereign customer (Korczynski and Ott, 2004, p. 577), instead wishing that HMRC continue enacting its traditional, more authoritative role (Waeraas, 2010):

I think they [HMRC] are trying to show that HMRC isn't an ogre, a miserable organisation, which drags money out of people. They are trying to show that their role is essential to society, using the customer concept. I suppose they are trying to create a new image for what they're doing. However, the customer concept is the wrong route for this (FTSE 100 Company Tax Director \#16).

In summary, corporate taxpayers present a distinctive view of what constitutes 'moral' tax compliance. Some corporate taxpayers even question if the issue of morality should be invoked at all when considering tax compliance. At the same time, corporate taxpayers resist HMRC's organisational identity change towards a greater customer orientation to which they are subject. Thus, policy-driven organisational identity change is no straightforward matter. As evident in our next empirical section, the issue of morality is central to public and media concerns about tax avoidance, and continues to inform the dynamics of organisational identity for HMRC.

\section{Public and Media: 'Tax Avoidance (Sheltering) Is Immoral'}

Whilst policy makers and HMRC senior management may try to blend enablement with the longstanding core practice of regulation, the quote below, from a $\mathrm{BBC}$ news item, highlights the fact that the wider public hold a very pejorative view of HMRC's identity change. They regard legal obligation and moral obligation as decoupled in the process of HMRC enacting its identity change. In essence, the wider public still perceives large corporate taxpayers as avoiding tax. They particularly focus upon the tax practices of those visible MNCs, more so in times of global financial downturn and the disproportionate effect of this upon poorer citizens:

Although tax avoidance, as practised by News Corp, is well within the law, the general public struggle to sympathise (BBC News, 1999). 
Reflecting this, the UK telecommunications company Vodafone has been particularly singled out by public demonstrations for its abusive avoidance of tax. As part of this abusive tax avoidance, Vodafone had been in dispute with HMRC for ten years over a tax avoidance scheme relating to the acquisition of a German company, which was settled within the UK Court of Appeal in 2010 (Houlder, 2010). A report from the Treasury Committee (2011) concerned with the administration and effectiveness of HMRC starkly presents public concern about tax avoidance:

159. A particular source of controversy has been HMRC's settlement of large tax cases involving corporations. Allegations have been made in the press that cases have been settled inappropriately for a lower yield than might otherwise have been achieved. ...

163. The public needs to be assured that cases involving large sums of money are being settled correctly. Equally it is unfair on HMRC staff and damaging to public confidence that the Department can be the subject of repeated allegations it cannot refute, even if they are groundless (Treasury Committee, 2011).

In the quote above, we see that the Treasury Committee invokes diminished public confidence in HMRC as it moves towards an enabling role. Buttressed by negative media commentary, this constitutes a threat to the latter's organisational legitimacy.

Picking up on such concerns, the UK's more left-leaning broadsheet newspaper, The Guardian, has been running a high-profile campaign to highlight tax avoidance by MNCs. The media reflects the public view that HMRC acts as a regulator to the tax affairs of large corporations and is thus beholden to the public to make visible, in a transparent way, their tax dealings with large corporations. As another dimension of being virtuous, HMRC is also expected to behave equitably with taxpayers, whether powerful MNCs or 'the man [sic] on the street'. For example, on 13 May 2011, Phillip Inman reported:

HM Revenue \& Customs has failed to provide details of a deal that allowed Goldman Sachs to avoid millions of unpaid tax after other firms settled similar disputes, according to a prominent member of a powerful parliamentary committee. The lack of disclosure in the long-running dispute with the US investment bank meant there was a danger the public would think there was 'one rule for some companies, and another for individual taxpayers', said Labour MP Chuka Umunna. Without directly attacking the appearance of preferential treatment for the US investment bank, Umunna said he was concerned that the case echoed the tax deal with Vodafone that led to demonstrations and protests by the campaigners UK Uncut. Vodafone was accused of saving £6bn in tax after it agreed a deal with HMRC (Inman, 2011).

Meanwhile, high-profile charities also reinforce concerns that the public have about tax avoidance, elevating the problem to one of global significance. They highlight that a virtuous regulatory organisation is not one that encourages inequity between the rich corporate and poor individuals, as the former are allowed to manage their tax affairs in a self-interested way:

[Our] report seeks to expose the scandal of a global taxation system that allows the world's richest to duck their responsibilities while condemning the poorest to stunted development, even premature death .... It is mostly about the world's transnational 
Tuck

corporations wielding their enormous power to avoid the attentions of the tax man with devastating results (Christian Aid, 2008, p. 1).

Reflecting public pressure and media attention, the transcripts of oral evidence given to the Parliamentary Public Accounts Committee (House of Commons Committee of Public Accounts, 2008) are revealing of political and wider public concern about the role of HMRC:

Q4 Chairman: You see what surprises me is that many people will be as astonished by this as I was. If we look at 1.12, what we see there is a third of large businesses pay no corporation tax at all. That is extraordinary. Do you think that members of the public, if they were watching this, would find that very strange.

Mr. Hartnett (Chairman, HMRC): I think members of the public would be interested to know why that is (House of Commons Committee of Public Accounts, 2008, p. 21).

So, despite promotion of organisational identity change towards enablement, even the chairman of HMRC is forced to admit that the public may be angry that a significant proportion of corporate taxpayers are able to avoid tax payment completely. Further, it seemed that he did not anticipate such a response from the public. The most senior management in HMRC did not keep an eye on the mirror to assess its image from the perspective of those outside the organisation as it engaged in identity change (Dutton and Dukerich, 1991). That the most senior manager in HMRC did not hold his ground around the virtue of enablement highlights how HMRC's core practice of regulation is decoupled from its new organisational identity as customer-focused and enabling corporate tax avoidance.

In summary, on the basis that an enabling role is necessary to support wealth creating activity, we might anticipate societal concerns about tax avoidance of corporate taxpayers are reduced. However, we note ongoing concerns expressed in the media and some very public (and often hostile) citizen reaction to those corporate taxpayers deemed to engage in tax avoidance. Given the current financial deficit faced by the UK and other governments, and subsequent reduction in public spending, the collection of tax becomes a more important moral matter for society, which has implications for organisational identity orientated towards the customer.

\section{DISCUSSION AND CONCLUSION}

Our study reveals that different external stakeholders have different views of the organisational identity change from 'regulator' to enabler' that HMRC engages in. External stakeholders contest changing organisational identity, most significantly focusing upon the moral purpose of HMRC, and whether the latter remains a 'virtuous organisation' (Moore, 2005). Even the corporate taxpayers that HMRC seek to serve exhibit distaste for the customer concept (Alford, 2002; Du Gay, 2000; Clarke et al., 2007; Needham, 2006; Rosenthal and Peccei, 2007). In short, the increasing customer orientation of HMRC impacts how external stakeholders perceive it is discharging its moral purpose, and so threatens the legitimacy of HMRC. 
In Moore's (2005) terms, pursuit of external goods - customer satisfaction - has driven out the regulatory practice at the core of HMRC. Society holds HMRC to its traditional role as regulator of the large corporate taxpayer, whom the public regard as 'villains'. The 'damaged' moral identity of HMRC impacts negatively upon the social and psychological contracts between taxpayers and the government regarding tax payments. Taxpayers are more compliant when they agree with tax laws being imposed (Vihanto, 2003) and when the political process is recognised to be fair and legitimate (Feld and Frey, 2007). Citizens expect the government to provide services as a quid pro quo for paying their taxes. However, this social and psychological contract may break down if organisational identity is compromised. The House of Commons Committee of Public Accounts, in its report in November 2012, when discussing the small payments of tax by multinationals and the associated lack of detail of HMRC's approach, noted that 'this undermines public confidence in the tax system and in HMRC which could have a negative impact for wider tax compliance' (House of Commons Committee of Public Accounts, 2012, p. 3). Specifically, we suggest that HMRC, as a regulative organisation, runs the risk of undermining its legitimacy as it seeks to distance itself from its traditional authoritative and bureaucratic organisational identity, and orientates too much towards the customer (Waeraas, 2010).

Extending analysis beyond our specific empirical case, we emphasise that the moral purpose of PSOs is a significant contemporary discourse (Sveningsson and Larsson, 2006). Moral purpose is particularly important within PSOs, given associated vague and oft contradictory sets of values held by various stakeholders, around which are required difficult trade-offs, and which may prove challenging to manage (Cheney and Vibbert, 1987; Christensen and Legreid, 2007; Waeraas, 2010). In their eagerness to please customers, we argue that policy makers, and senior managers within PSOs, may think they can credibly project any impression they like to the customer, no matter what their past heritage holds. However, government regulatory organisations have legitimacy around their authoritative role and coercive powers, which is underpinned by a certain moral view of their function held by society. This coheres around the rule of law, justice, democracy, objectivity, accountability and the common good that constitutes the basis of the virtuous organisation (Moore, 2005). Should moral claims go unheeded, PSOs run the risk of losing the support of external constituents in a way that may threaten their search for legitimacy and survival (Hatch and Schultz, 2002; Teram, 2010), in which case policy makers and senior managers, when engaging in organisational identity change, might pay more attention to managing the mirror so that their image aligns with the expectations of external stakeholders (Dutton and Dukerich, 1991). In this light, we note that the media is taking more interest in the private lives of organisations, including PSOs, and is keen to expose any divergence between corporate images and organisational actions. Thus, PSOs have increased exposure to critical voices, which means creating and maintaining identity is even more problematic (Albert and Whetten, 1985).

Regarding further research, our analysis is based upon a single empirical case. The furore from the public and the media around tax avoidance may render organisational identity change from regulator to enabler particularly challenging. However, we suggest many PSOs have increased societal expectations regarding 
Tuck

their moral purpose, and there is a need for more research into changing organisational identity in such contexts. Such research is required to fuel open public debate about organisational identity reconstruction that follows policy reform, more so when characterised by moral ambiguity (Hatch and Schulz, 2002; Teram, 2010). Finally, noting some senior managers looked in the mirror (Dutton and Dukerich, 1991) and raised concerns about their organisation's legitimacy as a regulatory agency, we encourage more research to examine the changing organisational identity of HMRC from an internal perspective.

\section{REFERENCES}

Aberbach, J. and Christensen, T. (2007). The Challenges of Tax Modernizing Administration, Public Policy and Administration, Vol. 22, No. 2, pp. 155-182.

Albert, S. and Whetten, D.A. (1985). Organizational Identity, in L.L. Cummings and B.M. Staw (eds), Research in Organizational Behaviour, Vol. 7, pp. 263-295, Greenwich, CT: JAI Press.

Alford, J. (2002). Defining the Client in the Public Sector: A Social-Exchange Perspective, Public Administration Review, Vol. 62, No. 3, pp. 337-346.

Ashforth, B. and Mael, F. (1996). Organizational Identity and Strategy as Context for the Individual, in J.A.C. Baum and J.E. Dutton (eds), Advances in Strategic Management, Vol. 13, pp. 19-64, Greenwich, CT: JAI Press.

Barney, J.B. and Stewart, A.C. (2000). Organizational Identity as Moral Philosophy: Competitive Implications for Diversified Corporations, in M. Schultz, M.J. Hatch and M.H. Larson (eds), The Expressive Organization: Linking Identity, Reputation, and the Corporate Brand, pp. 11-35, Oxford: Oxford University Press.

BBC News (1999). Tax Free: Rupert Murdoch's Zero Status, BBC News, 25 March, available from: <http://news.bbc.co.uk/2/hi/special_report/1999/02/99/e-cyclopedia/302366. stm>, accessed 3 March 2013.

Berg, A. (2006). Transforming Public Services: Transforming the Public Servant? International Journal of Public Sector Management, Vol. 19, No. 6, pp. 556-568.

Bockel, J. and Noordegraff, M. (2006). Identifying Identities: Performance-Driven, But Professional Public Managers, International Journal of Public Sector Management, Vol. 19, No. 6, pp. 585-597.

Brown, A.D. (2001). Organization Studies and Identity: Towards a Research Agenda, Human Relations, Vol. 54, No. 1, pp. 113-121.

Brunsson, N. and Sahlin-Andersson, K. (2000). Constructing Organizations: The Example of Public Sector Reform, Organization Studies, Vol. 21, No. 4, pp. 721-746.

Caron, D.J. and Giauque, D. (2006). Civil Service Identity at the Crossroads: New Challenges for Public Administrations, International Journal for Public Sector Management, Vol. 19, No. 6, pp. 543-555.

Cheney, G. and Vibbert, S.L. (1987). Corporate Discourse: Public Relations and Issue Management, in F.M. Jablin, L.L. Putnam, K.H. Roberts and L.H. Porter (eds), Handbook of Organizational Communication: An Interdisciplinary Perspective, pp. 165-194, Newbury Park, CA: Sage.

Christensen, T. and Legreid, P. (2007). Transcending New Public Management: The Transformation of Public Sector Reforms, Burlington, VT: Ashgate.

Christian Aid (2008). Death and Taxes: The True Toll of Tax Dodging, May 2008, London: Christian Aid, available from: <http:/ / www.christianaid.org.uk/images/deathandtaxes.pdf>, accessed 28 April 2012. 
Clarke, J., Newman, J., Smith, N., Vidler, E. and Westmarland, L. (2007). Creating CitizensConsumers: Changing Publics and Changing Public Services, London: Sage Publications.

Duncan, G. (2006). Tax Is Hurting British Competitiveness, The Times, 13 March.

Du Gay, P. (2000). In Praise of Bureaucracy, London: Sage.

Dutton, J.E. and Dukerich, J.M. (1991). Keeping an Eye on the Mirror: Image and Identity in Organizational Adaptation, Academy of Management Journal, Vol. 34, No. 3, pp. 517-554.

Eisenhardt, K.M. (1989). Building Theory from Case Study Research, Academy of Management Review, Vol. 14, No. 4, pp. 532-550.

Feld, L. and Frey, B. (2007). Tax Compliance as the Result of a Psychological Tax Contract: The Role of Incentives and Responsive Regulation, Law and Policy, Vol. 29, No. 1, pp. 102-120.

Gephart, R.P. (1993). The Textual Approach: Risk and Blame in Disaster Sensemaking, Academy of Management Journal, Vol. 36, No. 6, pp. 1465-1514.

Gioia, D.A., Schultz, M. and Corley, K.G. (2000). Organizational Identity, Image, and Adaptive Instability, Academy of Management Review, Vol. 25, No. 1, pp. 63-81.

Golden-Biddle, K. and Rao, H. (1997). Breaches in the Boardroom: Organizational Identity and Conflicts of Commitment in a Nonprofit Organization, Organization Science, Vol. 8, No. 6, pp. 593-611.

Hannan, M.T., Baron, J.N., Hsu, G. and Kocak, O. (2006). Organizational Identities and the Hazard of Change, Industrial Corporate Change, Vol. 15, No. 5, pp. 755-784.

Hatch, M.J. and Schultz, M. (2002). The Dynamics of Organizational Identity, Human Relations, Vol. 55, No. 8, pp. 989-1018.

He, H. and Baruch, Y. (2010) Organizational Identity and Legitimacy under Major Environmental Changes: Tales of Two UK Building Societies, British Journal of Management, Vol. 21, No. 1, pp. 44-62.

He, H. and Brown, A. (2013). Organizational Identity and Organizational Identification: A Review of the Literature and Suggestions for Future Research, Group \& Organization Management, Vol. 38, No. 1, pp. 3-35.

Her Majesty's Revenue and Customs (2005). The Whole Customer Vision, Practice and Design Principles, London: HMRC, available from: <http:// webarchive.nationalarchives.gov.uk/ 20110203224846/ http://customs.hmrc.gov.uk/channelsPortalWebApp/channelsPortal WebApp.portal?_nfpb=true\&_pageLabel=pageVAT_ShowContent\&id=HMCE_PROD1 _024818\&propertyType=document>, accessed 3 March 2013.

Her Majesty's Revenue and Customs (2006). Working with Large Business: Providing High Quality Service - Improving Tax Compliance, London: HMRC, available from: <http:// webarchive.nationalarchives.gov.uk/20140109143644/http://www.hmrc.gov.uk/lbo/ operating-model.pdf $>$, accessed 21 January 2010.

Her Majesty's Revenue and Customs (2007). Approach to Compliance Risk Management for Large Business, London: HRMC.

Her Majesty's Revenue and Customs (2009). Working in Partnership: An Update for HMRC's External Stakeholders, London: HRMC, available from: <http://www.hmrc.gov.uk/ about/wip-booklet.pdf >, accessed 27 November 2011.

Her Majesty's Treasury and Her Majesty's Revenueand Customs (2011). Tackling Tax Avoidance, March, London: HMRC, available from: <http://cdn.hm-treasury.gov.uk/2011budget_ taxavoidance.pdf $>$, accessed 25 August 2011.

Hoggett, P. (2006). Conflict, Ambivalence, and the Contested Purpose of Public Organizations, Human Relations, Vol. 59, No. 2, pp. 175-194.

Hood, C. (1991). A Public Management for All Seasons?, Public Administration, Vol. 69, No. 1, pp. 3-19.

Horton, S. (2006). New Public Management: Its Impact on Public Servant's Identity, International Journal of Public Sector Management, Vol. 19, No. 6, pp. 533-542. 
Tuck

Houlder, V. (2010). Tax Officials to Soften Stance on Avoidance, Financial Times, 19 August.

House of Commons Committee of Public Accounts (2008). Management of Large Business Corporation Tax, HC 302, Thirtieth Report of Session 2007-08, London: The Stationery Office.

House of Commons Committee of Public Accounts (2012). HM Revenue \& Customs: Annual Report and Accounts 2011-12, HC 716, 3 December, London: The Stationery Office.

Humphreys, M. and Brown, A.D. (2002). Narratives in Organizational Identity and Identification: A Case Study of Hegemony and Resistance, Organization Studies, Vol. 23, No. 3, pp. 421-447.

Inman, P. (2011). MP Demands Details of Deal to Let Goldman Sachs Avoid Tax, The Guardian, 13 May, available from: <http://www.guardian.co.uk/business/2011/may/13/mpsdemand-details-of-deal-to-let-goldman-sachs-avoid-tax/print>, accessed 22 April 2013.

Korczynski, M. and Ott, U. (2004). When Production and Consumption Meet: Cultural Contradictions and the Enchanting Myth of Customer Sovereignty, Journal of Management Studies, Vol. 41, No. 4, pp. 575-599.

MacIntyre, A. (1984). After Virtue: A Study in Moral Theory, Notre Dame, IN: University of Notre Dame Press.

Martin, G., Currie, G. and Finn, R. (2009) Leadership, Service Reform and Public-Sector Networks: The Case of Cancer-Genetics Pilots in the English NHS, Journal of Public Administration Research \& Theory, Vol. 19, No. 4, pp. 769-794.

Meyer, J.W. and Rowan, B. (1977). Institutionalized Organizations: Formal Structure as Myth and Ceremony, American Journal of Sociology, Vol. 83, No. 2, pp. 340-363.

Meyer, R. and Hammerschmid, G. (2006). Public Management Reform: An Identity Project, Public Policy and Administration, Vol. 21, No. 2, pp. 99-115.

Miles, M. and Huberman, A. (1994). An Expanded Sourcebook: Qualitative Data Analysis, London: Sage.

Moore, G. (2005). Corporate Character: Modern Virtue Ethics and the Virtuous Corporation, Business Ethics Quarterly, Vol. 15, No. 4, pp. 659-685.

Moore, G. (2012). Virtue in Business: Alliance Boots and an Empirical Exploration of MacIntyre's Conceptual Framework, Organization Studies, Vol. 33, No. 3, pp. 363-387.

National Audit Office (1996). Change Management in the Inland Revenue: Report by the Comptroller and Auditor General, HC 140, Parliamentary Session 1995-96, 21 February.

Needham, C. (2006). Customer Care and the Public Service Ethos, Public Administration, Vol. 84 , No. 4, pp. 845-860.

Nielsen, R.P. (2006). Introduction to the Special Issue: In Search of Organizational Virtue Moral Agency in Organizations, Organization Studies, Vol. 27, No. 3, pp. 317-321.

Picciotto, S. (2007). Constructing Compliance: Game Playing, Tax Law and the Regulatory State, Law and Policy, Vol. 29, No. 1, pp. 11-30.

Pratt, M. (2009). From the Editors: For the Lack of a Boilerplate - Tips on Writing Up (and Reviewing) Qualitative Research, Academy of Management Journal, Vol. 52, No. 5, pp. 856-862.

PricewaterhouseCoopers (2013). The Tax and Morality Debate: The Impact on UK Businesses, 18 March, webcast, available from: <http://www.pwcplayer.com/webcasts/2013_03_ tax_and_morality/index.html>, accessed 2 April 2013.

Rondeaux, G. (2006). Modernizing Public Administration: The Impact on Organizational Identities, International Journal of Public Sector Management, Vol. 19, No. 6, pp. 569-584.

Rosenthal, P. and Peccei, R. (2007). The Work You Want, The Help You Need: Constructing the Customer in Jobcentre Plus, Organization, Vol. 14, No. 2, pp. 201-223.

Scott, S.G. and Lane, V.R. (2000a). A Stakeholder Approach to Organizational Identity, Academy of Management Review, Vol. 25, No. 1, pp. 43-62. 
Scott, S.G. and Lane, V.R. (2000b). Fluid, Fractured and Distinctive? In Search of a Definition of Organizational Identity, Academy of Management Review, Vol. 25, No. 1, pp. 143-144.

Sillince, J. and Brown, A. (2009). Multiple Organizational Identities and Legitimacy: The Rhetoric of Police Websites, Human Relations, Vol. 62, No. 12, pp. 1829-1856.

Skalen, P. (2004). New Public Management Reform and the Construction of Organizational Identities, International Journal of Public Sector Management, Vol. 17, No. 3, pp. 251-263.

Suchman, M. (1995). Managing Legitimacy: Strategic and Institutional Approaches, Academy of Management Review, Vol. 20, No. 3, pp. 571-610.

Sveningsson, S. and Larsson, L. (2006). Fantasies of Leadership: Identity Work, Leadership, Vol. 2, No. 2, pp. 203-224.

Teram, E. (2010). Organizational Change within Morally Ambiguous Contexts: Conflicting Post-Merger Discourses, Journal of Applied Behavioral Science, Vol. 46, No. 1, pp. 38-54.

Thomas, R. and Davis, A. (2005). Theorizing the Micro-Politics of Resistance: New Public Management and Managerial Identities in the UK Public Services, Organization Studies, Vol. 26, No. 5, pp. 683-706.

Treasury Committee (2011). Treasury - Sixteenth Report: Administration and Effectiveness of HM Revenue and Customs, 30 July, available from: <www.publications.parliament.uk/pa/ cm201012/cmselect/cmtreasy/731/73102.htm>, accessed 15 July 2011.

Tuck, P. (2013). The Changing Role of Tax Governance: Remaking the Large Corporate Taxpayer into a Visible Customer Partner, British Journal of Management, Vol. 24, No. S1, pp. S116-S131.

Vihanto, M. (2003). Tax Evasion and the Psychology of the Social Contract, Journal of SocioEconomics, Vol. 32, No. 2, pp. 111-125.

Waeraas, A. (2010). Communicating Identity: The Issue of Core Value Statements in Regulative Institutions, Administration and Society, Vol. 42, No. 5, pp. 526-549.

Weber, M. (1964) [Talcott Parsons (ed.)]. The Theory of Social and Economic Organization, New York, NY: Free Press.

Yin, R. (2004). Case Study Research: Design and Methods, Thousand Oaks, CA: Sage. 